\title{
Comparison of Halal Product Consumer Behavior: Based on Muslim Majority and Minority Areas and Religiosity Aspect
}

\author{
Siti Dyah Handayani ${ }^{1,{ }^{*}}$ Roisah Iftinani Nur Azizah ${ }^{1}$ \\ ${ }^{1}$ Universitas Muhammadiyah Yogyakarta, Indonesia \\ ${ }^{*}$ Corresponding author.E-mail: siti_dyah@umy.ac.id
}

\begin{abstract}
This research aims to analyze the comparison of Muslim consumer behavior towards halal products between the majority and minority Muslim areas based on religiosity aspect related to the educational background of pesantren (Islamic boarding schools) and non-pesantren. The sampling technique in this research used non-probability sampling with a purposive sampling method. This research chose a sample of Muslims who lived in Purbayan and Ngupasan District in Yogyakarta. Questionnaires disseminated to 100 respondents were used as data collection methods, and an independent sample t-test was employed as data analysis. This research's results showed that there was no difference in Muslim consumer behavior in the majority and minority areas. The religiosity aspect also revealed no difference in consumer educational background of pesantren and non-pesantren. This research is expected to be worthy to the communities both as consumers and producers, as well as recommendations for managing the halal processed food industry for the government and all stakeholders in increasing halal product consumption among the society, especially in Yogyakarta.
\end{abstract}

Keywords: Consumer Behavior, Religiosity, Muslim, Halal.

\section{INTRODUCTION}

Indonesia is a country with the largest Muslim population globally (209.1 million people), indicating that $87.2 \%$ of the population is Muslim (Pew Research Center, 2017). Hence, the market opportunity for halal products in Indonesia is tremendous, so that research on halal products' consumer behavior is substantial. Although most Indonesian people have a Muslim background, the behavior of consuming halal food is not necessarily in line with it. A Muslim may not always behave in an Islamic manner, especially in consuming halal food [21].

According to Engel et al. [13], the factors influencing consumer behavior come from environmental influences (including culture, social class, personal influence, family, situation) and individual differences (consisting of consumer resources, involvement and motivation, knowledge, attitudes, personality, lifestyle, and demographics). In line with this, a Muslim in a Muslim minority environment will behave differently from a Muslim in a Muslim-majority environment. The level of a person's religious commitment through several processes will greatly determine his intention to behave in consuming halal food.

In public, someone with a high religious commitment (religiosity) is someone with an educational background of pesantren and lives in an environment that supports religious law, such as living in a Muslim-majority area or living in a family with religious observance. In this study, religiosity is seen from the pesantren's formal educational background because they are considered to have a higher understanding of religious knowledge and are accustomed to living in accordance with Islamic law. Thus, these people are considered capable of applying religious knowledge, one of which is consuming halal products. The comparison was made to Muslim consumers in Yogyakarta City by taking Purbayan Village in Kotagede Sub-district as a Muslim majority area, where Kotagede is known as 'Kota Santri/the City of Santri,' while Ngupasan Village in Gondomanan Subdistrict is a Muslim minority area, where the 'Chinatown' exist. The research subjects were public by choosing foods, such as bread and cakes, as the research objects because bread and cakes were easily obtained and consumed daily. 


\section{THEORETICAL FRAMEWORK}

Halal is defined as something that can be done, where the Sharia justifies, and the doer does not get sanctions from Allah SWT. Meanwhile, the antonym is haram, which means everything or cases prohibited by Islamic law; if abandoned, the doer will receive a reward, and if done, it will cause sin [17]. Islam teaches about eating halal and good food (thayyib), as stated in the Al-Quran in the following verses:

"O mankind, eat from whatever is on earth [that is] lawful and good and do not follow the footsteps of Satan. Indeed, he is to you a clear enemy." (Q.S. Al Baqarah: 168)

As a country with a Muslim majority, Indonesia has its institution to protect Muslim consumers' needs in consuming halal products, namely, Lembaga Pengkajian Pangan Obat-obatan dan Kosmetika Majelis Ulama Indonesia or abbreviated as LPPOM MUI. Under the Majelis Ulama Indonesia (Indonesian Ulema Council), LPPOM MUI is in charge of deciding whether consumption products, both food and non-food, such as cosmetics and medicines, are halal or permissible and good for consumption by Muslims in Indonesia.

Consumer behavior is defined as the dynamics of interaction between influence and awareness, behavior, and the environment where humans exchange life aspects [16]. In this research, the theory of behavior used is the Theory of Planned Behavior, where three main predictors influence an individual's intention to perform a behavior: attitude toward the behavior, subjective norm, and perceived behavioral control [3].

Further, attitude is an essential area of study in psychology because it is considered influential, and even the main determining factor in individual behavior towards objects or concepts (Omar et al., 2008). The definition of the attitude itself is a comprehensive evaluation by a person for a concept [16] so that the attitude is privacy and situational depending on how consumers evaluate the concepts and environmental situations around them that may encourage an attitude. Ajzen (2005) said that subjective norms are a function based on a belief called normative belief, which is a belief about the agreement and/or disagreement that comes from people and groups affecting individuals (significant others), such as parents, spouses, close friends, coworkers, or others on a behavior.

Specifies perceived behavioral control as perceived ease or difficulty in performing a behavior [2]. The more individuals perceive many supporting factors and few inhibiting factors to perform a behavior, the more control they feel over the behavior and vice versa, the fewer individuals feel concerning the supporting factors and many inhibiting factors to perform a behavior, the individual will tend to perceive themselves as difficult to do that behavior [3].
Based on the study's results of Indonesian Muslim consumers who lived in Banten and Bali, some differences could be seen from the measurement of the average score of respondents on the three determinant factors; respondents in Bali had higher attitudes and perceptions of behavioral control in consuming halal food than in Banten [23]. It indicated that minority groups in Bali, who are predominantly Hindu, tended to be more limited and difficult to obtain halal food so that Muslims could be motivated to have a more controlling attitude that came from themselves in deciding to consume halal food [23]. In line with this study's results, Muslim consumers who lived in Muslim minority areas would be more careful in consuming halal food than consumers who lived in Muslim-majority areas.

H1: There are significant differences in consumer behavior of halal products in Muslim majority and minority areas.

Meanwhile, religiosity is often identified with diversity. Religiosity is defined as how far a person's knowledge is, how strong his belief is, how much he practices worship and obeys the rules, and how deep is his appreciation of the religion he adheres. For a Muslim, religiosity can be seen from the extent of knowledge, belief, implementation, and appreciation of Islam's religion [17]. States that religiosity can be termed as a situation that exists within an individual that encourages them to behave in accordance with their adherence to religion [18]. Uncovered a significant difference in the application of religion to pesantren respondents compared to those of Islamic middle school and public senior high school respondents [11]. Based on this explanation, it can be stated as follow:

H2: There is a significant difference in religiosity's level towards halal products' consumer behavior with an educational background of pesantren and non-pesantren.

\section{RESEARCH METHODS}

This study examined the comparison of Muslim consumer behavior towards halal products for consumers in the Purbayan area, Kotagede sub-district, which was a Muslim majority area, with the Ngupasan area, Gondomanan sub-district (Chinatown), which was a Muslim minority area. The objects studied in this study were bread and cake food products. This study involved 100 respondents.

The data used in this study were primary data, obtained directly from filling in a structured questionnaire using a Likert scale (with weights ranging from 1 for those who strongly agreed to 5 for those who strongly disagreed). The sampling technique employed was Non-Probability sampling with a purposive sampling method, in which the sample members' characteristics included Muslim communities who lived in Purbayan and Ngupasan Village and aged over 17 years. The interviews involving five informants as representatives of 
community members were conducted to complement the quantitative findings.

The research model is as follows:

Figure 1. Research Model

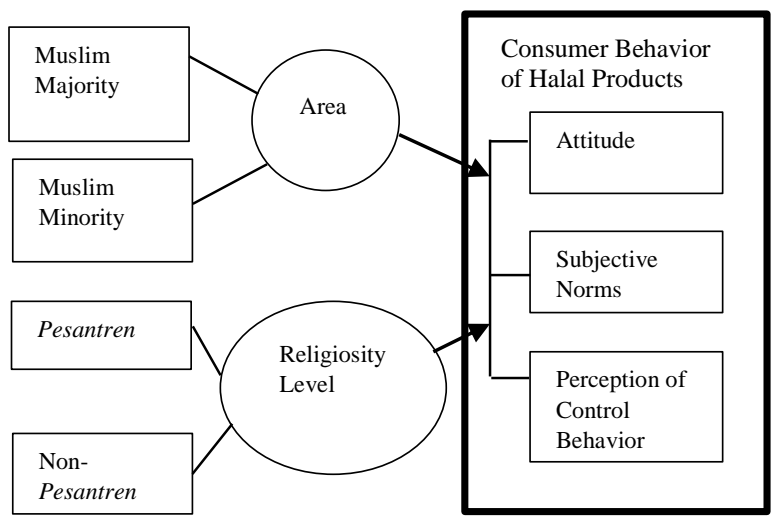

Table 1. Sample Proportion Calculation

\begin{tabular}{|c|c|c|}
\hline Village & Calculation & Sample \\
\hline $\begin{array}{c}\text { Purbayan } \\
\text { (Muslim Majority) }\end{array}$ & $\frac{9.784}{13.681} \times 100=71,51$ & 72 \\
\hline $\begin{array}{c}\text { Ngupasan } \\
\text { (Muslim Minority) }\end{array}$ & $\frac{3.897}{13.681} \times 100=28,48$ & 28 \\
\hline & Total & 100 \\
\hline
\end{tabular}

Source: Processed data

\section{RESULT AND DISCUSSION}

This study measured Muslim consumers' behavior, known from data on attitudes, subjective norms, and behavior control perceptions. Each variable's average number was described in this section and then analyzed using the Independent sample t-test.

Based on the results on the aspects of attitudes and perceptions of behavior control, Muslim majority groups and Muslim minorities had a probability of 0,621 and 0,309 (>0,05, not significant), while the subjective norm aspect had a probability of $0,036(<0,05$, significant $)$.

It revealed no difference in consumer behavior as measured through attitude aspects, and behavioral control perceptions between the majority Muslim respondent group domiciled in Purbayan and the Muslim minority respondent group lived in Ngupasan. However, on the subjective norm aspect, it was found that there were differences between groups of respondents in the two areas.

These results are in line with Engel et al. [13], which disclosed that consumer behavior for purchasing goods and services was influenced by environmental factors and individual differences. These environmental differences were unconsciously influenced through culture, social class, personal influence, family, and situations. It could be seen by the existence of significant differences in subjective norms. Moreover, the results showed that there was no difference in attitude variables and perceptions of behavioral control in the two areas due to the characteristics of Yogyakarta City, which is a city with a Muslim majority population so that both the understanding of religion and the socio-cultural environment in both areas were still dominated by the Islam influence.

This study's results are also in accordance with the research on religiosity's aspects of halal meat consumers' behavior by [12] towards Indonesian Muslim consumers who lived in Jakarta and Melbourne. This study's results indicated that behavioral control was one of the most significant determinants of interest in consuming halal meat, but there was no significant difference in behavior control in the two locations. This result is in line with the informant's statement:

"So far, I consume halal food for myself because I have been actively participating in kajian since I was a teenager, so the belief to consume halal food is part of worship. Even though quite a lot of Muslim residents here, but many do not care, so as much as possible, I invite my family or my friends to eat halal food." (The second informant). 
Table 2. Comparison of Consumer Behavior in Muslim Majority and Minority Areas

\begin{tabular}{|c|c|c|c|c|}
\hline \multirow[t]{3}{*}{ No } & \multirow[t]{3}{*}{ Indicator } & \multicolumn{2}{|c|}{ Average Value } & \multirow[t]{3}{*}{ Sig. } \\
\hline & & Purbayan & Ngupasan & \\
\hline & & (Muslim Majority) & (Muslim Minority) & \\
\hline & ATTITUDE & & & \\
\hline 1. & Buying bread and cakes with MUI halal certified & 4,46 & 4,29 & 0,288 \\
\hline 2. & Buying bread and cakes beside MUI halal certified & 3,56 & 3,57 & 0,947 \\
\hline 3. & Eating their own choice of bread and halal cakes & 4,31 & 4,14 & 0,312 \\
\hline 4. & Halal as the main consideration to consume & 4,61 & 4,54 & 0,588 \\
\hline 5. & $\begin{array}{l}\text { "Halal" stamp becomes the main consideration in } \\
\text { choosing a bakery and cake shop. }\end{array}$ & 4,42 & 4,29 & 0,527 \\
\hline \multirow[t]{4}{*}{6.} & $\begin{array}{l}\text { Muslim bakery and cake shops are the main consideration } \\
\text { in choosing. }\end{array}$ & 4,11 & 4,25 & 0,429 \\
\hline & Total & 4,25 & 4,18 & $\mathbf{0 , 6 2 1}$ \\
\hline & Percentage & $85 \%$ & $84 \%$ & \\
\hline & SUBJECTIVE NORMS & & & \\
\hline 1. & $\begin{array}{l}\text { Consuming halal bread and cake products due to family } \\
\text { demands }\end{array}$ & 2,93 & 3,96 & 0,000 \\
\hline 2. & $\begin{array}{l}\text { Consuming halal bread and cake products due to public } \\
\text { demands }\end{array}$ & 2,82 & 2,68 & 0,546 \\
\hline 3. & $\begin{array}{l}\text { Consuming halal bread and cake products due to } \\
\text { government demands }\end{array}$ & 2,75 & 2,89 & 0,543 \\
\hline \multirow[t]{4}{*}{4.} & $\begin{array}{l}\text { Consuming halal bread and cake products due to religious } \\
\text { leader }\end{array}$ & 3,11 & 3,79 & 0,008 \\
\hline & Total & 2,90 & $\mathbf{3 , 3 3}$ & $\mathbf{0 , 0 3 6}$ \\
\hline & Percentage & $\mathbf{5 8 \%}$ & $67 \%$ & \\
\hline & PERCEPTION OF BEHAVIOR CONTROL & & & \\
\hline 1. & The halal label must be clearly visible. & 4,31 & 4,46 & 0,280 \\
\hline 2. & Eating bread and cakes because of religious teachings & 4,44 & 4,61 & 0,347 \\
\hline 3. & Encouraging families to consume halal bread and cakes & 4,29 & 4,54 & 0,089 \\
\hline 4. & Encouraging relatives to eat halal bread and cakes & 4,21 & 4,32 & 0,460 \\
\hline 5. & Encouraging companion to eat halal bread and cakes & 4,22 & 4,14 & 0,619 \\
\hline 6. & Encouraging friends to eat halal bread and cakes & 4,11 & 4,21 & 0,541 \\
\hline 7. & Encouraging religious leader to eat halal bread and cakes & 3,81 & 3,89 & 0,687 \\
\hline 8. & $\begin{array}{l}\text { Encouraging community/public to eat halal bread and } \\
\text { cakes }\end{array}$ & 3,97 & 4,11 & 0,427 \\
\hline \multirow[t]{3}{*}{9.} & Controlling the consumption of halal bread and cakes & 4,14 & 4,39 & 0,132 \\
\hline & Total & 4,17 & 4,30 & $\mathbf{0 , 3 0 9}$ \\
\hline & Percentage & $83 \%$ & $86 \%$ & \\
\hline
\end{tabular}

Source: Processed data

The following table contains testing the differences between the two sample groups with the educational background of pesantren and non-pesantren by using the Independent sample test. The results are as follows:

Table 3. Comparison of Consumer Behavior Based on the Religiosity Level

\begin{tabular}{|c|c|c|c|c|}
\hline \multirow[t]{2}{*}{ No } & \multirow[t]{2}{*}{ Indicator } & \multicolumn{2}{|c|}{ Average Value } & \multirow[t]{2}{*}{ Sig. } \\
\hline & & Pesantren & Non-Pesantren & \\
\hline & ATTITUDE & & & \\
\hline 1. & Buying bread and cakes with MUI halal certified & 4,36 & 4,42 & 0,736 \\
\hline 2. & Buying bread and cakes beside MUI halal certified & 3,32 & 3,63 & 0,226 \\
\hline 3. & Eating their own choice of bread and halal cakes & 4,23 & 4,27 & 0,810 \\
\hline 4. & Halal as the main consideration to consume & 4,64 & 4,58 & 0,694 \\
\hline
\end{tabular}




\begin{tabular}{|c|l|c|c|c|}
\hline 5. & $\begin{array}{l}\text { "Halal" stamp becomes the main consideration in choosing a bakery } \\
\text { and cake shop. }\end{array}$ & 4,36 & 4,38 & 0,908 \\
\hline 6. & $\begin{array}{l}\text { Muslim bakery and cake shops are the main consideration in } \\
\text { choosing. }\end{array}$ & 4,09 & 4,17 & 0,691 \\
\hline & Total & $\mathbf{4 , 1 7}$ & $\mathbf{4 , 2 4}$ & $\mathbf{0 , 5 2 6}$ \\
\hline & Percentage & $\mathbf{8 3 \%}$ & $\mathbf{8 5 \%}$ & \\
\hline & SUBJECTIVE NORMS & & \\
\hline 1. & Consuming halal bread and cake products due to family demands & 3,09 & 3,26 & 0,571 \\
\hline 2. & Consuming halal bread and cake products due to public demands & 3,00 & 2,72 & 0,264 \\
\hline 3. & Consuming halal bread and cake products due to government & 2,86 & 2,77 & 0,711 \\
\hline 4. & Encouraging religious leader to eat halal bread and cakes & 3,36 & 3,28 & 0,771 \\
\hline & Total & $\mathbf{3 , 0 8}$ & $\mathbf{3 , 0 1}$ & $\mathbf{0 , 7 4 3}$ \\
\hline & Percentage & $\mathbf{6 2 \%}$ & $\mathbf{6 0 \%}$ & \\
\hline & PERCEPTION OF BEHAVIOR CONTROL & & & 0,535 \\
\hline 1. & The halal label must be clearly visible. & 4,27 & 4,37 & 0,387 \\
\hline 2. & Eating bread and cakes because of religious teachings & 4,36 & 4,53 & 0,688 \\
\hline 3. & Encouraging families to consume halal bread and cakes & 4,41 & 4,35 & 0,922 \\
\hline 4. & Encouraging relatives to eat halal bread and cakes & 4,24 & \\
\hline
\end{tabular}

\section{Source: Processed data}

Based on the test results, it was known that the attitude aspect of the pesantren group and the nonpesantren group had a probability of $0,526(>0,05$, not significant), while the subjective norm aspect of the pesantren group and the non-pesantren had a probability of 0,743 (>0,05, not significant). The probability of perceived behavioral control aspects between pesantren and non-pesantren groups was 0,936 (> 0,05, not significant). These results indicated no difference in consumer behavior between the respondent group with the pesantren education background and the respondent group who did not have a pesantren educational background.

Religiosity has more to do with how religious a person is as a person and less with how religious a person is in practicing religious provisions [10]. Each individual does not have a similar absolute value in each religiosity indicator (religious doctrine, religious practice, and spirituality). Even though the religiosity indicator was high (having a pesantren educational background), the low individual's behavior in consuming halal food could occur because someone with a good understanding of religious knowledge (religious doctrine) might not be maximized in the dimension of practicing religious teachings. This study's results align with the comparative research results on halal products' consumer behavior in Banten and Bali conducted by [23]. There was no significant correlation between the pesantren and consumer behavior's educational background in consuming halal food, especially in Banten.

\section{CONCLUSION}

Based on the analysis results, it could be concluded that there was no difference in consumer behavior of halal bread and cake products as measured through attitude variables and perceptions of behavioral control between groups of respondents in Muslim majority and minority areas. However, there was a difference in the subjective norm variable between the majority Muslim respondent group domiciled in Purbayan, and the Muslim minority respondent group lived in Ngupasan. At the religiosity level, there was also no difference in consumer behavior of halal bread and cake products measured through aspects of attitudes, subjective norms, and perceptions of behavioral control seen from the educational background of pesantren and non-pesantren.

This research limitations that can be opportunities for future research include the coverage of research subjects, such as consumers in other big cities in Indonesia, and the comparisons of consumption behavior of halal products on other respondents' characteristics, such as gender, education level, income, and profession, which are interesting to research. This study used formal pesantren and non-pesantren as aspects of religiosity, which can be developed in other environmental aspects, such as family background, work environment, and others.

\section{REFERENCES}

[1] Afendi, N. A., Azizan, F. L., \& Darami, A. I. (2014). Determinants of halal purchase intention: case in Perlis. International Journal of Business and Social Research, 4(5), 118-123.

[2] Ajzen, Icek. (1991). The Theory of Planned Behavior. Organizational Behavior and Human Decision Processes, 50, 179-211.

[3] Ajzen, Icek. (2005). Attitude, Personality, and Behavior second edition. USA: Open University Press. Downloaded from 
https://psicoexperimental.files.wordpress.com/ on 4 December 2017.

[4] Albelaikhi, A. A. (1997). Development of a Muslim religiosity scale.

[5] Ali, M. Y. (2014). Australian Multicultural Consumer Diversity: A Study on Muslim Consumers. Perception towards Halal Labelling. In Proceedings of the Australia New Zealand Marketing Academy Conference.

[6] Arikunto, Suharsimi (2010). Prosedur Penelitian: Suatu Pendekatan Praktek. Jakarta: Rineka Cipta.

[7] Astogini, D., Wahyudin, W., \& Wulandari, S. Z. (2014). Aspek Religiusitas Dalam Keputusan Pembelian Produk Halal (Studi tentang labelisasi halal pada produk makanan dan minuman kemasan). Jurnal Ekonomi Bisnis dan Akuntansi (JEBA), 13(1).

[8] Bonne, Karijn, et al. "Determinants of halal meat consumption in France." British Food Journal 109.5 (2007): 367-386.

[9] Daryanto, (2005). Evaluasi Pendidikan. Jakarta: Rineka Cipta.

[10] Edewor, D. O. (2008). Prophetic and Pseudo-Active Contributions of Religious Entities to the Political Process in Nigeria. Codesria: 12th General Assembly. Retrieved 06 April 2018, from Codesria: http://www.codesria.org/IMG/pdf/Dennis_Onome_ Edwor.pdf.

[11] Ismail, W. (2009). Analisis Komparatif Perbedaan Tingkat Religiusitas Siswa di Lembaga Pendidikan Pesantren, MAN, dan SMUN. Lentera Pendidikan: Jurnal Ilmu Tarbiyah dan Keguruan, 12(1), 87-102.

[12] Jusmaliani; Hanny, N. (2009). Religiosity Aspect in Consumer Behaviour: Determinants of Halal Meat Consumption. Asean Marketing Journal, Vol.I No. 2.

[13] Listyorini, Sari. (2012). Analisis Faktor-Faktor Gaya Hidup dan Pengaruhnya Terhadap Pembelian Rumah Sehat Sederhana (Studi pada Pelanggan Perumahan Puri Dinar Mas PT. Ajisaka di Semarang). Jurnal Administrasi Bisnis 1.1

[14] Nashori, Fuad. (2002). Agenda Psikologi Islam. Yogyakarta: Pustaka Pelajar.

[15] Omar, Wan Marhaini Wan et al. (2008). An Analysis of the Muslim Consumers' Attitudes toward 'Halal' Food Products in Kelantan. Proceeding ECER Regional Conference.

[16] Peter, J. Paul dan Olson, Jerry C. (2013). Consumer behavior: Perilaku Konsumen Dan Strategi Pemasaran Jilid 1. Edisi Kesembilan. Jakarta: Salemba Empat.
[17] Qardhawi, Y. (1997). Norma dan Etika Ekonomi Islam. Jakarta: Gema Insani Press.

[18] Rakhmat, J. (2004). Meraih Kebahagiaan. Bandung: Simbiosa Rekatama Media.

[19] Riduwan. 2013. Skala Pengukuran VariabelVariabel Penelitian. Bandung: Alfabeta.

[20] Rois, Ekawati L.H (2016). Pengaruh Religiusitas, Norma Subjektif dan Perceived Behavioral Control Terhadap Niat Membeli Produk Makanan Ringan Berlabel Halal (Studi Pada Mahasiswa Muslim Fakultas Ekonomi Universitas Negeri Yogyakarta). Fakultas Ekonomi Universitas Negeri Yogyakarta: Yogyakarta.

[21] Soesilowati, Endang Sri (2009). Peluang Usaha Produk Halal di Pasar Global Perilaku Konsumen Muslim dalam Konsumsi Makanan Halal. Jakarta (ID): P2E-LIPI

[22] Soesilowati, E. S. (2010). Business opportunities for halal products in the global market: Muslim consumer behaviour and halal food consumption. Journal of Indonesian Social Sciences and Humanities, 3, 151-160.

[23] Soesilowati, Endang Sri, dan Yuliana, Chitra Indah (2013). Komparasi Perilaku Konsumen Produk Halal di Area Mayoritas dan Minoritas Muslim. Jurnal Ekonomi Pembangunan Vol 21, No. 2, Desember 2013.

[24] Sugiyono. (2010). Metode Penelitian Bisnis. Cetakan ke-11. Alfabeta. Bandung.

[25] Sugiyono. (2011). Metode Penelitian Pendidikan (Pendekatakan Kuantitatif, Kualitatif, dan R\&D). Bandung: Alfabeta

[26] http://www.pewresearch.org/facttank/2017/01/31/worlds-muslim population-morewidespread-than-you-might-think/. Retrieved 23 November 2017.

[27] http://kependudukan.jogjaprov.go.id/olah.php?mod ule $=$ statistik $\&$ periode $=9 \&$ jenisdata $=$ penduduk $\&$ ber dasarkan=agama \&prop $=34 \& \mathrm{kab}=00 \& \mathrm{kec}=0$. Retrieved 23 November 2017.

[28] http://www.halalmui.org/mui14/index.php/main/go _to_section/58/1366/page/1 Retrieved December 4, 2017.

[29] http://kependudukan.jogjaprov.go.id/olah.php?mod ule $=$ statistik $\&$ periode $=9 \&$ jenisdata $=$ penduduk $\&$ ber dasarkan=agama $\&$ prop $=34 \& \mathrm{kab}=00 \& \mathrm{kec}=0$. Retrieved March 20, 2018. 